\title{
Spanish Speculations on the Rise of the English Novel: The Romantic, the Picaresque and the Quixotic
}

\author{
PEDRO JAVIER PARDO
}

\section{THEORIES OF THE RISE OF THE NOVEL}

Few books have had such a pervasive and permanent influence on any field of English studies as Ian Watt's 1957 monograph The Rise of the Novel: Studies in Defoe, Richardson and Fielding. Apart from coining the universally accepted phrase to designate the appearance of that new form of prose narrative in eighteenth-century Britain, Watt made current an explanation of it which soon became the explanation. This was based on a combination of literary, socio-economic and ideological reasons: the spread of formal realism, anchored in philosophical empiricism and formal because it 'does not reside in the kind of life it presents, but in the way it presents it' ${ }^{\text {' }}$; the expansion of the reading market, as a result of wider and easier access to books; and the emergence of middle-class individualism, the conjunction of capitalism and Protestantism giving shape to the bourgeois ethos. According to Watt, the novel provided a realistic representation of modern experience catering for an enlarged, mainly middle-class reading public and promoting their worldview; in other words, the novel gave expression to the modernity that made it possible by changes in epistemology, material conditions and ideology. In so doing, Watt combined a formalist or intrinsic and a materialistic or extrinsic approach to present the rise of the novel as an exclusively British affair, dismissing any foreign influences or intervention. As a matter of fact, he excluded those who he may have felt were the most serious contenders to the claim of priority in what we could call the race for the rise because they did not fit into his prescription of formal realism or into his alignment of the new genre with modernity: Cervantes and the 
picaresque, on the one hand; French fiction of the late seventeenth and early eighteenth centuries, on the other (see for example pp. 26, 30, 33, et passim).

Watt's book has remained the cornerstone for any study addressing the rise of the novel, even if to take issue with it. 'The shadow cast by The Rise of the Novel is so long,' claims David Blewett, 'that general studies of the early novel are still written in its shade.' 2 Or, as Richard Kroll put it, 'qualifying and attacking The Rise of the Novel has become the ground of a number of books almost as important in their own right': Watt has 'positively as well as negatively, determined the course of the major studies to have appeared in recent years' ${ }^{3}$ Most of these books, like Blewett's edited volume, are either expansions or rebuttals of Watt's arguments, and occasionally a combination of both, as Kroll demonstrates in his excellent overview of the matter (pp. I-24). Despite their differences with Watt and with each other, the major studies on the rise of the novel after Watt have inherited his emplotment of it as an English affair, only explicable in terms of the British context. They share, in Lennard Davis's terms, an osmotic and, I would add, local approach to the issue; that is, they see the novel as a response to and an absorption or assimilation of external circumstances, of literature's material and historical conditions, in Britain. ${ }^{4}$ In this sense, it is not unreasonable to say that most theories of the rise of the English novel are insular insofar as they ignore the previous development of the genre on the continent as well as the role of translation and literary exchange. Furthermore, the majority also ignore the intrinsic explanation of the rise of novel that Watt's formal realism at least implied, even if encapsulated in the extrinsic or historicist one.

This oversight is the source of my first contention here: we cannot fully understand the rise of the novel without acknowledging the foreign contribution and the relevance of form in such a rise. I use form in the broadest sense to refer to the internal patterning of the novel, how it gives textual shape to the world through narrative situations and devices, plot and formulae, discourse and language; in short, I mean the means of representation instead of the world represented. Of course, form is a privileged carriageway for cultural traffic across national boundaries, since it implies ways of looking at and encoding experience which can be recycled beyond particular contexts. In this sense, innovations in form are not just a response to a material or ideological milieu, but also to translation and transtextuality; they result not only from new contexts, but also from the transformation of previous texts, irrespective of the 
country or the language in which they were originally written. The rise of the novel is not simply a national but a transnational construction. So is the novel as a genre.

Curiously enough, this insight is as old as the major studies on the novel by Ortega y Gasset, Lukács, or Bakhtin (all of them predating Watt, although they were translated into English later). ${ }^{5}$ These studies have not been as influential on rise-of-the-novel scholars as Watt's, possibly because they originated on the continent and did not accord prominence to the eighteenth-century English novel. This is also the case of another more contemporary but similarly weighty advocate of the transnational approach, Franco Moretti, who embraces both the internal (form) and the external (culture) approach in his collection of essays by so many authors dealing with different national contexts and cross-cultural genres. ${ }^{6}$ The situation started to change, though, when Margaret Anne Doody openly challenged Watt's view of the rise of the novel by placing this far away and long ago, in Greek and Roman antiquity, and connecting it to what has traditionally been labelled as romance. ${ }^{7}$ A similar point had already been made some years earlier in a less polemical and more subdued way-actually so subdued that it passed quite unnoticed - by Hubert McDermott. ${ }^{8}$ And in the twentyfirst century: Cohen and Dever, and also Mander, the latter with the significant title Remapping the Rise of the European Novel, have argued the case for the transnational nature not just of the novel but of the eighteenth-century British novel, perhaps the final cue for the tide to turn; although the fact that their works (as well as Moretti's) are collaborative volumes points to what has always been the main problem: to integrate diverse literatures and cultures in a unified theory. ${ }^{9}$ In the opening paragraph of her introduction, Mander quotes Terry Castle's verdict that the topic of the rise of the novel has reached saturation point in order to plead for a rethinking that expands the geographical perspective from which it has been approached (p. I). After decades of being kept in the background, the transnational approach to the rise of the English novel is moving centre stage. This implies looking not just to Antiquity or to France, but to another contender usually neglected in this narrative of origins: Spain.

This brings us to the second contention of this paper: it is impossible to understand the rise of the novel in Britain without taking into account three narrative patterns, all of them of continental-hence foreign-origin, including two from Spain, namely, the romantic, the picaresque and the quixotic. Again I use pattern in the broadest 
sense to refer to narrative structures comprising both character and action and implying a characteristic way of organizing and arranging as well as understanding and representing experience; hence as a theoretical category based on specific and historical narrative practices and combining both plot form or mythos and mode in the sense these terms have been used by, for example, Scholes and Kellogg. ${ }^{10}$ These patterns in themselves do not explain the rise of the English novel, but without them any explanation of it is simply incomplete. And they undeniably call attention to the fact that the foundations of the novel do not lie just in classical romance but in the picaresque and quixotic manipulation of chivalric romance that first takes place in early modern Spain and is applied later and elsewhere, particularly in seventeenthcentury France, to other kinds of romance.

Only two scholars, to my knowledge, have understood the importance of the picaresque and the quixotic for the rise of the English novel, albeit in very different ways. One is Ronald Paulson, who studied them as patterns of the satiric tradition that he related to the emergence of realism in the eighteenth-century novel; the other is Walter Reed, who considered them the genuine expression of the ethos of opposition by which he defined the novel as a genre in a book that, in my view, has not had the impact it deserves. ${ }^{\text {II }}$ They both make clear that these patterns are not limited to Spain or Britain, but are also at work in French and German fiction. I am indebted to them-and of course to the three aforementioned continental founding fathers-for my de-historicized reworking of their insight, which I am going to illustrate by examining the work of one major eighteenth-century author. Smollett's novels are a meeting point of the romantic, the picaresque and the quixotic, and have been mostly neglected in accounts of the rise of the novel since Watt (see p. 290), I think, precisely because he is such a good example of the English indigenization of foreign patterns.

A TEST CASE: THE ROMANTIC, THE PICARESQUE AND THE QUIXOTIC IN SMOLLETT'S FICTION

The widespread and all too frequently inaccurate use of the terms romantic, picaresque and quixotic to refer to other works than those which originated them, has made these terms increasingly unreliable, problematic and confusing. This confusion derives largely from a feature, as far as narrative pattern is concerned, common to all: a journey and the episodic structure usually associated with it. This is no mere coincidence, 
but the result of a very simple fact: in historical as well as in formal terms, both the quixotic and the picaresque are patterned on the romantic. Furthermore, the three paradigms, more or less neatly separated in early modern Spanish fiction, merged and became blended in later French and English novels until they became difficult to separate. The inadvertent confusion of these patterns by scholars reflects their deliberate confusion by writers, springing from the common ground where the three of them originate and where they converge as they develop. Nonetheless, we need to distinguish between them in order to appreciate what is distinctive in them, how they evolve and are transformed, and hence their place in the history of the novel and, more specifically, its rise in Britain.

\section{Definitions}

The relationship between romances, picaresque novels and Don Quijote was aptly explained by Alexander Parker long ago when he wrote that 'the idealistic romances bred "anti-romances" in Spain, which [...] presented the crude and sordid. These anti-romances were either implicitly satirical of all heroism, like the picaresque novels, or deliberate parodies, like Don Quixote; in either case they emphasized the comic in order to counter the solemnity they satirized. ${ }^{\text {I2 }}$ As Parker highlights, the picaresque and the quixotic are both responses to romance, but in different ways: the picaresque as counter-genre, as a debased alternative to the idealized world of romance; the Quijote as parody, as an explicit critique of romance which incorporates it in order to criticize it. But, in so doing, the picaresque is also criticized by the romantic, and hence, as Claudio Guillén and Edward Riley have argued, if the picaresque is a response to chivalric romance, then the quixotic is a response to the picaresque as well as to the romantic: Don Quijote is both overt parody of the chivalric romance and covert counter-genre of the picaresque. ${ }^{13}$ This reveals the cursory identification of the quixotic with the picaresque so frequent in the English-speaking academic context to be a serious mistake. Cervantes offers an alternative to the idealized world of romance by including the picaresque into his diegetic universe, and to the debased world of the picaresque by including the romantic: the quixotic is neither one nor the other, but the superimposition of both. With these different sets of relationships in mind, the analysis of the romantic, picaresque and quixotic narrative patterns can transcend the common device of the journey as a means for weaving together a series of adventures on the road, at castle or inn, in court or city, and describe three narrative models 
which entail different kinds of hero, structure different kinds of plot, and imply different approaches to reality.

The ROMANTIC pattern, as illustrated by chivalric romances and especially by their Hispanic exemplars like Garci Rodríguez de Montalvo's Amadís de Gaula (i508), narrates how a boy or young man becomes a hero. His extraordinary origins bespeak his heroic fate and determine his life. He may be an orphan because he is a foundling, but he has a family and belongs to a community, and he undergoes a process of initiation which marks a transition from innocence to experience, ignorance to maturity, leading to full integration in a social order. As a representative of it, he will undertake a journey entailing a series of adventures and heroic exploits in order to preserve that order as well as to demonstrate his courage and his love for the heroine. These adventures elevate him to the zenith of his world, not only because he is successful but also because they often involve the recovery of the noble identity he lost as a foundling. The romantic pattern, in this sense, is one of exile and return not only in physical but also in psychological terms.

The romantic pattern is one of wish-fulfilment; the PICARESQUE, by contrast, is one of frustration, as El Lazarillo de Tormes (I 544) or Mateo Alemán's Guzmán de Alfarache (I 599, I604) make clear. It narrates how a boy or young man becomes an anti-hero. His origins are also extraordinary because they are unusually base and lowly, and they also determine him, but in this case for an anti-heroic destiny, for a life of misery and delinquency. Unlike the romantic hero, he is alone and isolated, homeless and fatherless, and the process of initiation, here involving not just loss of innocence but also deception and disillusion (engaño $y$ desengaño), entails the realization of his radical solitude. This launches him on his wanderings, prompting a series of itinerant adventures in which he practises roguery and deception, guile and wile, and involving the assumption of different conditions and stations as a means of living. His aim becomes self-preservation in a permanent conflict with - and not in support of -a hostile world from which he is alienated or estranged, a marginalized outsider. This conflict leads to a spiritual-if not material-nadir, usually implying a social compromise that leaves him in a position appositely described by Guillén as that of a half-outsider, someone only apparently integrated into a society from which he nonetheless is estranged, who can 'neither join nor actually reject his fellow men', who 'makes a pact [...] with the very same values he recognizes as empty'. ${ }^{14}$ That is why we can say that in the picaresque there is exile but no return. 
In contrast both to the romantic and the picaresque pattern, the QUIXOTIC one, as formulated in Cervantes's Don Quijote de la Mancha ( 1605 and $1_{615}$ ), is that of an anti-hero who wishes to become a hero, and, although at times and in a certain sense he succeeds, on the whole he fails. The basic narrative situation is a man's imitation of the romantic pattern, or, in more general terms, his attempt to live according to a certain idea of himself and of the world; but neither he nor the world are fit for his romantic imitation, especially the latter, which is one of roguery, deception and degradation close to the picaresque. Consequently, his endeavours result in failure and frustration. The quixotic pattern thus results from submerging the romantic one in a picaresque world and is the chronicle of their discrepancy and contrast. It puts side by side two sets of adventures: a romantic one constituted by how they are seen, perceived, experienced in Don Quijote's mind; and an anti-romantic one integrated by the same adventures as they actually take place, but also as they are experienced by his squire Sancho.

In all three narrative patterns the thread uniting the series of adventures is a journey, but its motivation or purpose turns it into a QUEST, albeit one of a very different kind in each case. It is worth noting, firstly, that the three protagonists of the quest - a knight errant, its opposite, a picaro, and a madman who thinks himself to be a knight errant-include several features which allow for variations in the pattern, or which explain why the narrative paradigm may recur in the absence of these figures. Thus the knight is also a lover, and, above all, a hero and paragon, an embodiment of a series of qualities in a state of perfection and purity. The delinquent is also any outsider or marginal figure, but also a trickster or rogue, or simply an anti-hero and pragmatist: someone ordinary, with lights and shadows, and living on his wits instead of on his guts, valuing benefits over morals, pleasure over duty. The madman is also an imitator and especially an idealist, that is, an individual who tries to shape his ordinary life in accordance with the ideal or with one idea which is hostile to such a life. Unlike the hero, he inadequately embodies that ideal, but its existence separates him from its absence in the antihero, thus becoming a mixture of both, that is, an anti-heroic hero or heroic anti-hero. Finally, the quest in all three cases usually implies a succession of fortunes and misfortunes in which chance plays a key role, but whereas in romance this is regulated by a benevolent Providence which elevates the hero to his final apotheosis, in the picaresque there is neither regulation nor elevation, at best an ambiguous ending wellsuited for the chaos and disorder of the represented world. In the quixotic 
there is both order and chaos in the simultaneous workings of a romantic mind which expects to be exalted and those of a picaresque world which abases him. This makes apparent the correlation of these patterns with three different modes of representing the world: romance, realism and a combination of both. In this respect, as in all others, the quixotic is a pattern of duality, discrepancy, contrast. The romantic derives from myth, the picaresque subverts it by offering a realistic antithesis, and the quixotic synthetically incorporates both and plays them against each other. ${ }^{15}$

\section{Roderick Random}

In the preface to Roderick Random (I748), Smollett acknowledges his debt to the French author Alain-René Lesage, author of the picaresque work Gil Blas (I7 5, I724 and I735), when he writes that 'the following sheets I have modelled on his plan'. ${ }^{16}$ This acknowledgement, together with the obvious picaresque features of the novel, have triggered a critical controversy about the nature and function of the picaresque in Smollett, in this case focusing mainly on whether Roderick is a picaro or not. Fortunately, we do not need to revisit and add to this controversy, since a picaro is not strictly necessary for a picaresque pattern to exist, as I hope to have made clear. In addition to this, we have seen that there are several ways in which the picaresque is related to the romantic and the quixotic, and this is an open invitation to hybridization. This was actually the case of Smollett's novels and of Roderick Random in particular, since this mixing of narrative models is really the source of the controversy. The modulations of the picaresque in Smollett pointed out by the critics can be explained by the presence of the romantic and the quixotic along with it. ${ }^{17}$

That the basic and initial narrative situation of the book is picaresque is beyond dispute: in the first chapter we learn how, one week after his birth, Roderick is orphaned, and the second is headed by the following caption: 'I grow up - am hated by my relations - sent to school neglected by my grandfather-maltreated by my master-seasoned to adversity-form cabals against the pedant-debarred access to my grandfather-hunted by his heir-demolish the teeth of his tutor' (p. 4). This reads like the typical picaresque situation: a young man in conflict with a world that marginalizes and mistreats him, and against which he retaliates using his wits and trickery, as his revenge on his master shows; or, in other words, a character fending for himself from an early 
age in a hostile environment. His only protection at this early stage is his uncle Bowling, but when misfortune deprives him even of this and he is betrayed by his supposed friends, his solitude and alienation are complete: 'I found myself,' he remarks, 'deserted to all the horrors of extreme want, and avoided by mankind as a creature of a different species, or rather as a solitary being, no ways comprehended within the scheme or protection of providence' (pp. 25-26).

This forces him to go into service as an apothecary journeyman, first in Glasgow and later in London, and thus initiate the rogue's progress through different trades and places, as successively mate to the surgeon of a war ship bound for the West Indies, servant at a lady's house in Sussex, soldier in a French regiment fighting in Germany, foppish fortune hunter in Paris, London and Bath, and, after the experience of prison, again naval surgeon sailing to Africa and South America. The novel thus follows the protean pattern of picaresque adventure, with the usual cycles of fortune and misfortune, the latter marking the transition between cycles. At the end of each cycle he has to start anew by resorting to a different scheme of life. Roderick is perfectly aware of this pattern when, reflecting upon his past life, he writes: 'If one scheme of life should not succeed, I could have recourse to another, and so to a third, veering about to a thousand different shifts, according to the emergencies of my fate, mithout forfeiting the dignity of my character, beyond a power of retrieving it, or subjecting myself wholly to the caprice and barbarity of the world' (emphasis added, p. I37).

Roderick's remark is made in the context of a comparison of his fate with that of Miss Williams. The difference between them at that stage of the novel makes clear the difference between a real picaro, in this case a female one, and Roderick: he has not forfeited the dignity of his character beyond the power of retrieving it. Although he has behaved and will behave in a roguish way on several occasions, he is not a real rogue, much less a delinquent, as Banter reminds him when commenting on his lack of qualifications for succeeding as a fortune hunter. The real rogues of the novel are many of the characters he encounters, who constitute a very interesting gallery of tricksters and delinquents. But Roderick is too innocent and noble, he has too much of the gentleman in him, because he actually is a gentleman. Both character and reader discover this when, in the final romantic anagnorisis resulting from a providential encounter, he finds his father and returns with him to Scotland, to his family estate that his father buys. This, rather than an isolated fact detracting from the picaresque nature of the novel or making it defective, is a clear signal of 
the romantic pattern framing the picaresque one. Smollett has made his character subject of both a picaresque and a romantic plot by turning him, in imitation of Lesage's Gil Blas, into a kind of heroic rogue, a hybrid of pragmatist and romantic hero. On the one hand, he shares the rogue's protean identity and is forced by his circumstance to change work and station; on the other hand, he is estranged at the beginning from his true identity as a gentleman and recovers it at the end after his picaresque experience. The romantic pattern of exile and return is thus made evident, so he is not finally the split half-outsider of the picaresque, but the fully integrated and exalted romantic hero. The picaresque quest for a rise in social and economic position in a chaotic world has given way to - or rather is framed by - the romantic one for recovery of that position in a providentially ordered universe. And, what is even more interesting, the facility with which the romantic and the picaresque are integrated makes explicit the structural affinities and the inverse correlation existing between them, the fact that the picaresque is the anti-romantic double or counterpart of the romantic. ${ }^{18}$

This romantic pattern is completed by a love plot which, like the recovery-of-identity plot, is alien to the picaresque universe but figures prominently in the romantic one, particularly in a variation of it represented by the French heroic romances of the seventeenth century. ${ }^{19}$ The love plot of Roderick and Narcissa in Roderick Random is quite obviously modelled upon these French narratives of love hindered by a series of obstacles (parental opposition, lowly origins, rivals, villains and all kinds of peripetia) that are eventually overcome. Narcissa is the typically romantic paragon and awakens in Roderick the kind of ideal love which is alien to the picaresque, but his lowly condition, the existence of rivals (first Sir Timothy and later Lord Quiverwit), and the opposition of Narcissa's brother prevent the union. After the indispensable romantic feats of arms by the hero, who rescues the heroine from the assault of Sir Timothy and defeats Lord Quiverwit in a duel for the love of the heroine, his recovery of fortune and position removes the obstacles and paves the way to marriage.

Curiously enough, this romantic love plot is used by Smollett, in conjunction with certain figures and adventures of the picaresque plot, as part of a quixotic pattern which plays them against each other. Romantic love is soon coupled with its anti-romantic counterpart: the cook-wench's and the dairymaid's infatuation with Roderick mirrors the latter's passion for Narcissa in a lower sphere. Roderick appears simultaneously as subject of a romantic love plot and object of an anti-romantic one, and 
the contrast between both cannot but be ludicrous. This is evident when he sleeps with a peasant girl, Nanette, and remembers his Narcissa, remembrance fuelling rather than diminishing his lust (p. 240). The difference between this episode and former similar ones which express the distinctively picaresque sexual hunger is the presence of Narcissa. As heroine of the romantic love plot, she establishes the ideal to which the other women and love plots pursued by Roderick do not live up, of course to their satirical and comic detriment, usually in an explicit way through reference to Narcissa, as in Nanette's case. This is also the case of the three women Roderick pursues in his roguish career as a fortune hunter. There is no time here to analyse these episodes in detail, but it is apparent how the coquettish and vain Melinda, the aged Miss Withers who smells of garlic, and the twisted and satirical Miss Snapper are all anti-romantic and comic foils to Narcissa. This quixotic pattern is underlined by an explicit allusion to Narcissa when dealing with Melinda (p. 296), by calling Miss Withers quixotic names ('my hoary Dulcinea', 'the Duenna,' p. 304), and by the physical presence of Narcissa side by side with Miss Snapper in Bath. It is also underlined by the anti-romantic or picaresque nature of his antagonists, the comic captain Oregan in Melinda's case, the cowardly highwaymen in Miss Snapper's.

The double plot of romantic and picaresque adventures which distinguishes the quixotic is thus created, with the same comic, mockromantic and satirical effects observable in Don Quijote, although with an important difference in relation to the Spanish masterpiece: the two sets of adventures do not correspond to the inner and outer world of the protagonist, but are both part of the outer world of a hero who shares features of the romantic and the anti-romantic and acts in both series in a real and not imagined fashion. Romance is thus granted objective and not just subjective existence, something that Cervantes intimated through the secondary plots and characters of the interpolated stories, but was only effected in the transformation of the quixotic pattern taking place in seventeenth-century France; and not only in Smollett's acknowledged model, Gil Blas, but above all in Paul Scarron's Roman comique $\left(\mathrm{I} 65^{\mathrm{I}}-57\right)$. Fielding adopted Scarron's title to name the new species of writing that he adumbrated in Foseph Andrems (1742) by imitating the manner of Cervantes (as he claimed in the subtitle) and adding the Scarronian turn comic romance. ${ }^{20}$ And, just when Roderick Random was published, Fielding was finishing his Tom fones (I749), where he availed himself of the same dual hero of a double plot of romantic and picaresque adventures that we have seen in the former. 
Since the almost simultaneous publication of Roderick Random and Tom fones makes it impossible to claim influence by either of them on the other, this uncanny coincidence can only be explained by their common source: the quixotic narrative pattern re-elaborated in France as a way of juxtaposing romance and the picaresque in order to represent the dual, ambivalent, inclusive nature of reality, a more comprehensive world embracing the romantic and the anti-romantic, which Cervantes had already portrayed in Don Quijote and Fielding and Smollett adapted in Roderick Random and Tom fones. In these latter, it is worth noting, the quixotic does not imply the presence of quixotism in the hero, further evidence that we are not dealing with the transference of characters or episodes (although there are some remarkable borrowings, for example the panzaic companions, Strap and Partridge, respectively), but of formal patterns, as is made explicit in Smollett's words invoking a plan on which his work is modelled or Fielding's subtitle invoking the manner of Cervantes. To avoid this confusion of matter and manner encouraged by the term quixotic, which can refer either to the hero and his world or to the narrative pattern which shapes both, perhaps Cervantine is a more suitable term for the novel form that embraces and transforms both romance and the picaresque. The Cervantine explains not just Roderick Random, but most other novels by Smollett and some of the major contributions to the rise of the English novel in the eighteenth century.

\section{THE CERVANTINE APPROACH TO THE RISE OF THE NOVEL}

After examining the interaction of the romantic, the picaresque and the quixotic in Roderick Random, it is evident that the rise of the novel does not imply a break with romance or its defeat by realism, but the evolution from or absorption of romance into realism. The year that saw the publication of The Rise of the Novel also witnessed the appearance of the book which first convincingly argued this insight from a transnational perspective, Northrop Frye's The Anatomy of Criticism. Frye's theory of modes and displacement, developed further in his later study of romance, The Secular Scripture, accounted for the history of narrative as a series of essential plot formulae or mythoi progressively displaced from myth through romance to mimesis and irony by their gradual approximation to the world of ordinary experience. ${ }^{2 \mathrm{I}}$ Bearing this in mind, it is reasonable to affirm that the picaresque and the quixotic represent the two fundamental patterns for the realistic displacement of romance from which the novel emerges. Of course, as we have just seen, 
they differ in the way they displace romance, but they both establish a dialogue with it, even though this is only implicit in the picaresque. The nature and significance of this dialogue is best understood if we again turn to another transnational theorist of the novel, Mikhail Bakhtin. For Bakhtin, the novel brings into dialogical contact different languages, discourses and voices, and this dialogism both originates in and encompasses the dialogization of previous genres or literary forms. ${ }^{22}$ From this perspective, we can consider the picaresque and the quixotic as two different forms of dialogizing romance, which can be characterized as anti-romantic and comic romantic. One implies the negation of romance as a falsification of reality in order to posit a world deprived of the ideal, an oppositional or anti-romantic realism which equates reality with the anti-literary, as Reed has aptly argued. The other simultaneously affirms that romance is a falsification and a dimension-even if just a subjective one - of the real; it both acknowledges and questions romance by coupling it with its anti-romantic reverse, in order to produce a romantic or inclusive realism that presents reality as dialogic. This implies not just the interplay of romance and anti-romance but also the transformation of romance into a worldview in conflict with reality and other worldviews, a further implication of the quixotic pattern that will prove hugely productive in the later development of the novel, when the romantic disappears from the conflict of perspectives and discourses defining the genre according to Bakhtin, and that again may be best conveyed by the term Cervantine.

I think it is safe to affirm that much-if not most-eighteenthcentury fiction participates in this dialogue with romance and between worldviews along the lines described above, in that it follows the narrative patterns I have outlined. The romantic foundation has shifted from chivalric to French heroic romance, but continues to inform many eighteenth-century novels. These can be read as picaresque and Cervantine transformations of it, or, in other words, as anti-romantic and comic-romantic responses to it, as a brief review of significant examples suffices to demonstrate.

The connection of Defoe's fictional chronicles of criminal life to the picaresque and its anti-romantic depiction of the lowest steps of life, is particularly evident in Moll Flanders ( 1722 ), which is directly related to a Spanish female picaresque narrative, López de Úbeda's $\mathrm{La}$ picara fustina (1605; English translation by John Stevens, The Spanish Filt, I707). Defoe's picaresque connection was deftly argued by Javier Sánchez in his thesis and subsequently in the introduction to his edition 
of a recent Spanish translation of Moll Flanders, although without much impact on the rise of the novel debate (a good reminder of the foreseeable repercussions of my own remarks). ${ }^{23}$

Samuel Richardson, who constitutes with Defoe the backbone of Watt's theory, epitomizes, despite his condemnation of romance, the adherence to the romantic pattern and its quixotic displacement, as I have argued elsewhere. ${ }^{24}$ Suffice it to say here that the protagonist of Pamela (I740) is both a romantic heroine and a quixotic narrator, since her self-representation as heroine is coloured by her romantic imagination, which turns her into a quixotic figure. In parallel fashion, Richardson both follows the romantic pattern of damsel in distress and undermines it by letting us glimpse through her quixotism the antiromantic reality she distorts, both embodied and voiced by Mr B and Mrs Jewkes, who insistently draw our attention to her romantic emplotment and give more than a Cervantine flavour to the novel's dialogism. In a very original twist on this pattern, though, Pamela is not a comic romance, but a neo-romance (or a romanticized novel, in Reed's terms, p. I66), since romance is realistically displaced and dialogized in terms of epistemological inadequacy, but also legitimized by the heroine's success and its moral supremacy. Interestingly enough, at the end of the formative period of the British novel extending throughout the long eighteenth century, Walter Scott was to produce a variation of this neoromantic pattern in which youth and idealism equally legitimize romance but do not prevent its final defeat. His Waverley (I 8 I 4 ) features a quixotic hero who grows out of his romantic imagination in a maturation process running parallel to the displacement of romance in the historical world and into the historical novel.

There is no need to insist on Fielding's and Smollett's key part in the dissemination of the three narrative patterns, and particularly of their quixotic amalgamation, in the eighteenth-century novel. The romantic and dialogic basis underlying Fielding's novels, his theory and practice of comic romance, and his Cervantine connection have been studied. ${ }^{25}$ In Smollett's case, his alignment with comic romance has been obscured by his invocation of Lesage and his ensuing alliance to the tradition of the picaresque. Nevertheless, as we have seen, Cervantes is behind Lesage's manipulation of the picaresque and the quixotic pattern will emerge in full view in Launcelot Greaves ( $1760-6 \mathrm{I})$ - a deliberate imitation of Don Quixote which features a quixotic hero, written after the publication in I 755 of his well-known translation of the Spanish masterpiece - and then brought to splendorous fruition in Humphry Clinker (I77I), which, as 
I have shown elsewhere, can be considered the summit of the Cervantine novel in the eighteenth century. ${ }^{26}$ The tradition of comic romance, studied by Baker in Smollett as well as Fielding, ${ }^{27}$ also informs a host of lesser-known novelists and particularly of quixotic novels, from Richard Graves's The Spiritual Quixote (1773) to Charles Lucas's The Infernal Quixote (I80I), through political, sentimental and philosophical Quixotes in other novels now almost forgotten. Here the Cervantine paradigm was involved in what Marilyn Butler has called the mar of ideas, but with the peculiarity that it took part on both sides (Jacobin and anti-Jacobin).

What of women novelists? I propose to consider them last but not least because, as recent scholars have pointed out, in women's writing the presence of romance is more acutely felt. ${ }^{28}$ It would be surprising, therefore, if romance was not apparelled in anti-romantic, comic romantic or neo-romantic guise, and other facts reinforce this assumption. Richardson and his neo-romance was the avowed model for many women writers. Charlotte Lennox, one of the founding mothers of the novel, made use in The Female Quixote ( $175^{2}$ ) of female quixotism and the quixotic pattern both to mitigate the patriarchal anxiety produced by female reading and to give vent to female self-expression and selfrepresentation. This pattern was subsequently taken to fruition in the novel of female development by Burney, Edgeworth and Austen, female quixotism being progressively displaced but underlying a maturation process not too different - in narrative, not conceptual terms - from the one undergone by Waverley. ${ }^{29}$ For all these reasons, it becomes feasible to place eighteenth-century fiction by women in the narrative tradition I have outlined here and to envisage a development of the Cervantine model from Lennox to Austen. The traditional exclusion of women writers from the rise of the novel is even more difficult to sustain when romance is made to play an important part in it, and when the rise of the novel is considered a displacement as well as a dialogization of romance by realism.

The lesson Cervantes taught to the eighteenth-century novelists, either by the example of his own Don Quijote or through the offspring it spawned in France as well as in Britain, was how to write novels out of romance, turning the novel into a site for dialogism (not just between romance and reality but between alternative worldviews) and self-consciousness (the explicit awareness that the novel is not reality but a way of apprehending it through a romantic/fictional form). This, I think, gives much credence to Cervantes's competing claim to the paternity of the novel, and hence to a Cervantine theory of the rise 
of the novel. The claim is supported by still another one that, mad as it may seem, makes a lot of sense, like Don Quixote's reasonable madness (locura entreverada): even if it was not originally written in English, Don Quijote can be considered an eighteenth-century English novel. Not only was it available at the time in English translation, but there was a significant increase both in the quantity of its circulation and the quality of its reception. Let us not forget that, after Thomas Shelton's translation (I6I2, I620)-reworked by John Stevens in I700-and John Phillips's ( I687), the eighteenth century saw the publication of three new translations (Peter Motteux in 1700 and 1703 , Charles Jervas, or Jarvis, in $\mathrm{I}_{742}$, and Tobias Smollett in $\mathrm{I755}$ ), with more than twenty editions and reprints in all. This fact alone distinguishes Don Quijote as one of the most popular books of the century, at least as much as those by Defoe, Richardson or Fielding, as is proved by the vast number of references, quotations, comments and borrowings that Paulson has reviewed in his Don Quixote in England..$^{30}$

That is why Cervantes is one major - if not the foremost - novelist of eighteenth-century English literature, even though he was not English. John Richetti acknowledges this implicitly when discussing Don Quixote in his introduction - from which Watt is conspicuously absent-to a collection of essays on the eighteenth-century English novel. In Richetti's text, Watt's view of realism, shaped by Defoe and Richardson, is replaced by one deriving from Cervantes. This position is symptomatic of an ongoing process of internationalization of the English novel and of Cervantes's incorporation into English literary history, a process which might have started with some antecedents that place Cervantes at the inception of the English novel, even if their ambition was not ultimately realized..$^{3}$ Notwithstanding, positions such as Richetti's and his predecessors' are valuable reminders from within English literature of the absurdity of setting national boundaries to literature. Instead, a transnational view including the decisive part played by foreign models should displace the insularity which has defined narratives of the rise of the novel in Britain.

In this transnational view, I would add, form should be set at the centre, since literary history should chronicle not only the interplay of literature and its historical context, but also the birth and development of literary forms, their transmission and evolution. The manner of the novel is as important as its matter, since it gives shape to all the contexts surveyed in different accounts of the rise of the novel (economy and ideology, gender and class) and makes them coalesce in a work of art. 
Focusing on context is the best way to dismiss the role of form in the rise of the novel, since you cannot imitate or emulate contexts (at best they can be similar), only texts and the patterns they use to turn those contexts into narrative. And this is the territory where the legacy of Cervantes and the claim to at least his participation in the rise of the novel should be acknowledged, as Fielding makes perfectly clear when he writes that he is imitating his manner. Without this acknowledgement, you may well explain why the novel rose to existence, significance, and eminence, at the time it did in Britain; but not the way it did it.

\section{NOTES}

I Ian Watt, The Rise of the Novel: Studies in Defoe, Richardson and Fielding (London: The Hogarth Press, 1987), p. I I.

2 Eighteenth-Century Fiction, I2. 2-3 (2000), double issue on the Rise of the Novel edited by David Blewett, p. I4I.

3 The English Novel, edited by Richard Kroll (London: Longman, I998), pp. 2 and 4.

4 Lennard Davis, Factual Fictions: The Origins of the English Novel (New York: Columbia University Press, I983), pp. 2-8.

5 José Ortega y Gasset, Meditations on Quixote (New York: Norton, I96I[I9I4]); George Lukács, The Theory of the Novel (Cambridge: MIT Press, I97I[1920]); Mikhail Bakhtin, Problems of Dostoevsky's Poetics (Minneapolis: University of Minnesota Press, 1984[1929]) and The Dialogic Imagination: Four Essays (Austin: University of Texas Press, I98I). McKeon provides a good account of their theories of the novel in his contribution to the aforementioned issue of Eighteenth-Century Fiction, 'Watt's Rise of the Novel within the Context of the Rise of the Novel', pp. 253-276. For an overview of these and other theories, see also Theory of the Novel: A Historical Approach, edited by Michael McKeon (Baltimore: Johns Hopkins University Press, 2000).

6 The Novel, edited by Franco Moretti, 2 vols (Princeton: Princeton University Press, 2006 [200I]).

7 Margaret Anne Doody, The True Story of the Novel (London: Fontana Press, I998[1996]). Doody's observation on the exclusion of the foreign in English narratives of the rise of the novel merits note: 'The English performed a wonderful trick in persuading themselves that "The Rise of the Novel" took place in England in the eighteenth century. They eliminated the predecessors once so fully acknowledged, along with the transmissions outlined by Salmasius and Huet. Such historians had made the foreignness of fiction too visible. That foreignness at the root must be cut off' (p. 293).

8 Hubert McDermott, Novel to Romance: The 'Odissey' to 'Tom Fones' (London: Macmillan, I989).

9 The Literary Channel: The Inter-National Invention of the Novel, edited by Margaret Cohen and Carolyn Dever (Princeton: Princeton University Press, 2002); Remapping 
the Rise of the European Novel, edited by Jenny Mander, Studies in Voltaire and the Eighteenth Century, Io (Oxford: Voltaire Foundation, 2007).

Io Robert Scholes and Robert Kellog, The Nature of Narrative (Oxford: Oxford University Press, i966).

I I Ronald Paulson, Satire and the Novel in Eighteenth-Century England (New Haven: Yale University Press, 1967); Walter Reed, An Exemplary History of the Novel: The Quixotic versus the Picaresque (Chicago: University of Chicago Press, I98I).

I2 Alexander Parker, Literature and the Delinquent: The Picaresque Novel in Spain and Europe 1599-I753 (Edinburgh: Edinburgh University Press, I967), p. 8.

I3 Claudio Guillén, 'Genre and Countergenre: The Discovery of the Picaresque', in Literature as System: Essays toward the Theory of Literary History (Princeton: Princeton University Press, I97I), pp. I35-I58; Edward C. Riley, 'Romance, the Picaresque and Don Quixote I', in Studies in Honor of Bruce Wardropper, edited by Diane Fox and others (Newark: Juan de la Cuesta, I989), pp. 237-248.

I4 Claudio Guillén, 'Toward a Definition of the Picaresque', in Literature as System: Essays toward the Theory of Literary History (Princeton: Princeton University Press, I97I, pp. 7I-Io6), pp. 8o and Ioo. In my view, Guillen's account of the picaresque as genre and as myth, that is, as a narrative pattern, remains unsurpassed.

I5 For a detailed exposition of romance and realism as modes of representing reality see my La tradición cervantina en la novela inglesa del siglo XVIII (Salamanca: Ediciones Universidad de Salamanca, I997), available online at $<$ http://hdl.handle.net/ı0366/56699 $>$. The main ideas on this topic are summarized in 'El romance como concepto crítico-literario', Hesperia, 2 (I999), 79-II4.

I6 Tobias Smollett, The Adventures of Roderick Random, edited by Pierre-Gabriel Boucé (Oxford: Oxford University Press, I98I), p. xxxiv.

I7 The debate on the picaresque in Smollett is also represented in its essential positions-for or against the identification of Roderick Random and Smollett's novels with the picaresque - in monographs on Smollett. See Robert Giddings, The Tradition of Smollett (London: Methuen, I967), Paul-Gabriel Boucé, The Novels of Tobias Smollett (London: Longman, I976), and Robert Donald Spector, Tobias George Smollett (Boston: Twayne, I989). The more recent book-length studies on Smollett by John S. Skinner, Constructions of Smollett: A Study of Genre and Gender (Newark: University of Delaware Press; London: Associated University Presses, I996), and Jerry C. Beasley's Tobias Smollett, Novelist (Athens, GA and London: The University of Georgia Press, I998), have not added anything to this debate.

I 8 For the presence of romance in Roderick Random and Smollett's novels in general, see Michael Rosenblum, 'Smollett and the Old Conventions', Philological Quarterly, 55 (I976), 389-402, and also David K. Jeffrey, 'Roderick Random: The Form and Structure of a Romance', Revue belge de philologie et d'histoire, 58 (I980), 604-6I4. See also, on the connection to Lesage, Boucé and Roseann Runte, 'Gil Blas and Roderick Random: Food for Thought', The French Reviem, I (I977), 698-705.

I9 I am referring to the works also called in their day romans à longue haleine because of their extension, such as Polexandre (1632-37) and Citherée (1640-42) by Marin le Roy de Gomberville; Cassandra (I642-50), Cléopâtre (I648) and Faramond (I66I) by Gauthier de Costes de la Calprenède; and Ibrahim (I64I), Artamène, ou Le Grand Cyrus (I648-53), Clélie (г654-6г) and Almahide (г66 I-63), by Madeleine 
de Scudéry. Their combination of chivalric and Greek romance became hugely popular in Britain in the late seventeenth and early eighteenth centuries, as Lennox's Cervantine parody of them in The Female Quixote ( $175^{2}$ ) shows.

20 For an excellent treatment of Scarron's - as well as other French Cervantine imitators'-influence on Foseph Andrems, see Homer Goldberg, The Art of Foseph Andrems (Chicago: University of Chicago Press, I969), pp. 27-72.

2 I Northrop Frye, Anatomy of Criticism (Princeton: Princeton University Press, 1957) and The Secular Scripture: A Study of the Structure of Romance (Cambridge: Harvard University Press, 1976). Surprisingly enough, or perhaps not, since it is undoubtedly a direct consequence of the imprint and dominance of Watt's approach on the English debate on the rise of the novel, Frye has been absent from this debate. There is at least one recent exception in Scott Black's contribution - significantly entitled 'Quixotic Realism and the Romance of the Novel' (pp. 239-244) - to the first of three issues of Novel: A Forum on Fiction, 42:2 (2009), edited by Nancy Armstrong and devoted to theories of the novel now. Black aims to 'stage an imaginary debate' between Frye and Watt and proposes that 'thinking them side by side offers a way to begin to address a blind spot in some important recent accounts of the novel', since the 'participation in an older romance tradition is integral to both Fielding's novels and the genre more generally' (p. 239). He claims that 'the question we should be arguing is how novelists use the romance forms that not incidentally but integrally organize many of their works' (p. 240), and that is precisely what I am trying to do here. It is fair to acknowledge, though, that the question was first posed and given an enlightening answer by Sheridan Baker in 'The Idea of Romance in the Eighteenth Century Novel', Papers of the Michigan Academy of Science, Arts and Letters, 49 (I964), 507-522, and later by scholars such as Henry Knight Miller, 'Augustan Prose Fiction and the Romance Tradition', in Studies in the Eighteenth Century III, edited by R. F. Brissenden and J. C. Eade (Toronto: University of Toronto Press, I976), pp. 24I-255; Jerry C. Beasley, 'Romance and the "New" Novels of Richardson, Fielding, and Smollett', Studies in English Literature, I6 (I976), 437-450; and Melvyn New, “The Grease of God:” The Form of Eighteenth-Century English Fiction', Publications of the Modern Language Association, 9I (1976), 235-244.

22 The notion of dialogism and its relevance for the theory of the novel is aptly explored in Tzvetan Todorov, Mikhail Bakhtin: The Dialogical Principle (Minneapolis: University of Minnesota Press, I984), and Gary S. Morson and Caryl Emerson, Mikhail Bakhtin: Creation of a Prosaics (Stanford: Stanford University Press, 1990).

23 'La picaresca femenina española y su continuidad en Moll Flanders. Genología, genética literaria y rise of the novel' (University of Salamanca, I987), and 'Introducción', in Moll Flanders (Madrid: Cátedra, I999).

24 'Novel, Romance and Quixotism in Richardson's Pamela', Atlantis, i8 (1996), 306-336, and La tradición cervantina en la novela inglesa del siglo XVIII.

25 See, for example, besides Goldberg and McDermott, Sheridan Baker, 'Henry Fielding's Comic Romances', Papers of the Michigan Academy of Sciences, Arts and Letters, 45 (I960), 4I I-4I9; Henry Knight Miller, Henry Fielding's 'Tom Fones' and the Romance Tradition (Victoria: University of Victoria, I976); and James Lynch, Henry Fielding and the Heliodoran Novel: Romance, Epic, and Fielding's Nem Province of Writing (London and Toronto: Associated University Presses, I986). The articles on Fielding and Cervantes are too numerous to be listed here, but a selection of 
them can be found at the end of the entry on Fielding in the fifth volume of the Gran Enciclopedia Cervantina edited by Carlos Alvar (Madrid: Castalia, 2008), pp. 47I I-47I9. I deal extensively with the Cervantine manner in both Foseph Andrems and Tom fones in La tradición cervantina en la novela inglesa del siglo XVIII, later condensed with an extension of this manner to Thackeray in 'La tradición cervantina en la novela inglesa: de Henry Fielding a William Thackeray', in Entre Shakespeare y Cervantes: Sendas del Renacimiento, edited by Zenón Luís Martínez and Luís Gómez Canseco (Newark: Juan de la Cuesta, 2006), pp. 73-I I I.

26 'Tobias Smollett's Humphry Clinker and the Cervantine Tradition in EighteenthCentury English Fiction', in Cervantes in the English-Speaking World, edited by Darío Fernández-Morera and Michael Hanke (Kassel and Barcelona: Reichenberg, 2005), pp. I54-I64. The view I sketched there of the Cervantine conception of the novel in Roderick Random, which I have developed here, was quite different from the one predominant at the time in accounts of Smollett's novel and his debt to the picaresque, which did not detect Cervantes behind the picaresque. See, for example, David Skilton's otherwise excellent overview of both the picaresque and the quixotic in eighteenth-century English fiction, 'Quixotic and Picaresque Fiction', in Defoe to the Victorians: Tmo Centuries of the English Novel (Harmondsworth: Penguin, I985). The only exception to this situation is Juan Antonio Garrido Ardila's article on Cervantes in Roderick Random, subsequently re-published in his Cervantes en Inglaterra. El Quijote en los albores de la novela británica (Liverpool: Bulletin of Spanish Studies, Liverpool University Press, 2006). A close comparison between Ardila's views and mine, in this as in other matters, would show, however, that even if the issues tackled and the main contention are deceptively similar, the approach, manner, arguments and analysis are altogether different.

27 Sheridan Baker, 'Humphry Clinker as Comic Romance', in Essays on the EighteenthCentury Novel, edited by Robert Donald Spector (Bloomington and London: Indiana University Press, I966), pp. I 54-I64.

28 See Laurie Langbauer, Women and Romance: The Consolations of Gender in the English Novel (Ithaca: Cornell University Press, I990), and Deborah Ross, The Excellence of Falsehood: Romance, Realism, and Women's Contribution to the Novel (Lexington: University Press of Kentucky, I99I).

29 For this topic see Susan Fraiman, Unbecoming Women: Women British Writers and the Novel of Development (New York: Columbia University Press, I993), and Lorna Ellis, Appearing to Diminish: Female Development and the British Bildungsroman, I750-I850 (London: Associated University Press, I999).

30 Don Quixote in England (Baltimore: Johns Hopkins University Press, I998). It is a pity that Paulson did not address here the contribution of Cervantes's masterpiece to the rise of the novel in Britain, but only its reception in the eighteenth century. The same applies to The Cervantean Heritage: Influence and Reception of Cervantes in Britain, edited by Juan Antonio Garrido Ardila (London: Modern Humanities Research Association, 2009), or, in a broader international context, to International Don Quixote, edited by Theo D'haen and Reinder Dhondt (Amsterdam and New York: Rodopi, 2009). They provide a great deal of useful information on the British and international dissemination of Cervantes, but do not offer a poetics of the Cervantine novel or even a unified transnational focus, since the individual contributions are very disparate in methods and approaches. In this sense, they add little to the debate, 


\section{Spanish Speculations on the English Novel}

although, of course, some specific articles - in these and in other similar collections published in Spanish - offer occasional and valuable ideas in support of Cervantes's paternity of the novel. In this regard, a very convincing formulation of this claim in the context of the rise of the English novel debate can be found in Joan Resina's essay in Moretti's The Novel: 'The Short, Happy Life of the Novel in Spain' (vol. I, pp. 29I-3I2).

3I The Cambridge Companion to the Eighteenth-Century Novel, edited by John Richetti (Cambridge, Cambridge University Press, I996), pp. I-8. The naturalisation of Don Quijote by writers and readers in Britain, implied by its inclusion in an overview of English fiction, is even more evident in Dorothy Van Ghent's The English Novel: Form and Function (New York: Holt, Rinehart and Winston, 1953), and in Frederick Karl's The Adversary Literature. The English Novel in the Eighteenth Century: A Study in Genre (New York: Farrar, Straus and Giroux, I974). 


\section{Your short guide to the EUP Journals Blog http://euppublishingblog.com/}

A forum for discussions relating to Edinburgh University Press Journals

\section{The primary goal of the EUP Journals Blog}

To aid discovery of authors, articles, research, multimedia and reviews published in Journals, and as a consequence contribute to increasing traffic, usage and citations of journal content.

\section{Audience}

Blog posts are written for an educated, popular and academic audience within EUP Journals' publishing fields.

\section{Content criteria - your ideas for posts}

We prioritize posts that will feature highly in search rankings, that are shareable and that will drive readers to your article on the EUP site.

\section{Word count, style, and formatting}

- Flexible length, however typical posts range 70-600 words.

- Related images and media files are encouraged.

- No heavy restrictions to the style or format of the post, but it should best reflect the content and topic discussed.

\section{Linking policy}

- $\quad$ Links to external blogs and websites that are related to the author, subject matter and to EUP publishing fields are encouraged, e.g.to related blog posts

\section{Submit your post}

Submit to ruth.allison@eup.ed.ac.uk

If you'd like to be a regular contributor, then we can set you up as an author so you can create, edit, publish, and delete your own posts, as well as upload files and images.

\section{Republishing/repurposing}

Posts may be re-used and re-purposed on other websites and blogs, but a minimum 2 week waiting period is suggested, and an acknowledgement and link to the original post on the EUP blog is requested.

\section{Items to accompany post}

- A short biography (ideally 25 words or less, but up to 40 words)

- A photo/headshot image of the author(s) if possible.

- Any relevant, thematic images or accompanying media (podcasts, video, graphics and photographs), provided copyright and permission to republish has been obtained.

- Files should be high resolution and a maximum of $1 \mathrm{~GB}$

- Permitted file types: jpg, jpeg, png, gif, pdf, doc, ppt, odt, pptx, docx, pps, ppsx, xls, xlsx, key, mp3, m4a, wav, ogg, zip, ogv, mp4, m4v, mov, wmv, avi, mpg, 3gp, $3 g 2$. 